\title{
Valorization of Bio-Briquette Fuel by Using Spent Coffee Ground as an External Additive
}

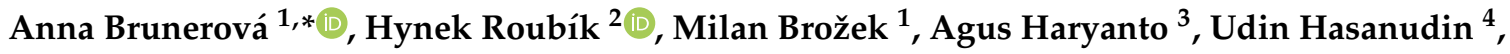 \\ Dewi Agustina Iryani ${ }^{5}$ (D) and David Herák ${ }^{6}$ \\ 1 Department of Material Science and Manufacturing Technology, Faculty of Engineering, Czech University of \\ Life Sciences Prague, Kamýcká 129, 16500 Prague, Czech Republic; brozek@tf.czu.cz \\ 2 Department of Sustainable Technologies, Faculty of Tropical AgriSciences, Czech University of Life Sciences \\ Prague, Kamýcká 129, 16500 Prague, Czech Republic; roubik@ftz.czu.cz \\ 3 Department of Agriculture Engineering, Faculty of Agriculture, University of Lampung, Jl. Sumantri \\ Brojonegoro 1, Bandar Lampung 35145, Republic of Indonesia; agus.haryanto@fp.unila.ac.id \\ 4 Department of Agro-industrial Technology, Faculty of Agriculture, University of Lampung, Jl. Sumantri \\ Brojonegoro 1, Bandar Lampung 35145, Republic of Indonesia; udinha@fp.unila.ac.id \\ 5 Department of Chemical Engineering, Engineering Faculty, University of Lampung, Jl. Sumantri \\ Brojonegoro 1, Bandar Lampung 35145, Republic of Indonesia; dewi.agustina@eng.unila.ac.id \\ 6 Department of Mechanical Engineering, Faculty of Engineering, Czech University of Life Sciences Prague, \\ Kamýcká 129, 16500 Prague, Czech Republic; herak@tf.czu.cz \\ * Correspondence: brunerova@tf.czu.cz; Tel.: +420-737-077-949
}

Received: 8 November 2019; Accepted: 15 December 2019; Published: 20 December 2019

\begin{abstract}
The present study investigates the quality changes of wood bio-briquette fuel after the addition of spent coffee ground (SCG) into the initial feedstock materials (sawdust, shavings) in different mass ratios (1:1, 1:3). Analysis of SCGs fuel parameter proved great potential for energy generation by a process of direct combustion. Namely, level of calorific value $\left(G C V=21.58 \mathrm{MJ} \cdot \mathrm{kg}^{-1}\right)$, of ash content $(A c=1.49 \%)$ and elementary composition $(C=55.49 \%, H=7.07 \%, N=2.38 \%$, $\mathrm{O}=33.41 \%$ ) supports such statement. A comparison with results of initial feedstock materials exhibited better results of SCG in case of its calorific value and elementary composition. Bulk density $\rho\left(\mathrm{kg} \cdot \mathrm{m}^{-3}\right)$ and mechanical durability $D U(\%)$ of bio-briquette samples from initial feedstock materials were following for sawdust: $\rho=1026.39 \mathrm{~kg} \cdot \mathrm{m}^{-3}, D U=98.44 \%$ and shavings: $\rho=1036.53 \mathrm{~kg} \cdot \mathrm{m}^{-3}$, $D U=96.70 \%$. The level of such mechanical quality indicators changed after the addition of SCG. Specifically, SCG+sawdust mixtures achieved $\rho=1077.49 \mathrm{~kg} \cdot \mathrm{m}^{-3}$ and $D U=90.09 \%$, while SCG + shavings mixtures achieved $\rho=899.44 \mathrm{~kg} \cdot \mathrm{m}^{-3}$ and $D U=46.50 \%$. The addition of SCG increased wood bio-briquettes energy potential but decreased its mechanical quality. Consequently, the addition of SCG in wood bio-briquette has advantages, but its mass ratio plays an important key role.
\end{abstract}

Keywords: solid biofuel; waste management; Coffea spp.; waste biomass; calorific value; mechanical durability

\section{Introduction}

A group of plants called Coffea L. (Rubiaceae family) bears the coffee cherries and contains more than 70 specific species. Nevertheless, only two of them are purposely cultivated as agriculture crops, namely, Coffea arabica (75\% of the world's production) and Coffea canephora (syn. Coffea robusta) ( $25 \%$ of the world's production) [1,2]. Coffee beverages have been produced and consumed for more than 1000 years. Currently, 400 billion cups of coffee are consumed every year [3]. Consequently, coffee represents one of the most valuable commodities in the world and the second-largest traded commodity after petroleum [4]. Its production has a significant influence on international relationships, 
economics, politics, and the trade of many developing countries. The coffee production industry, i.e., plant cultivation, cherries harvest, bean processing, product packaging, sale marketing, and final product transportation, offers job opportunities for millions of people [5].

Brazil belongs to the top countries in coffee production, as well as Vietnam, Indonesia, and Colombia. Together those countries generate more than $50 \%$ of the world's coffee production. Specific statistical data provided by the Food and Agriculture Organization of the United Nations (FAO) and by the International Coffee Organization (ICO) related to the coffee industry in the last years are expressed in Table 1.

Table 1. Worldwide coffee production in years 2014-2017 [6,7].

\begin{tabular}{ccccc}
\hline Year & $\begin{array}{c}\text { Harvested Area } \\
(\mathbf{H a})\end{array}$ & $\begin{array}{c}\text { Yield } \\
\mathbf{( H g \cdot H a}\end{array}$ & $\begin{array}{c}\text { Green Bean } \\
\text { Amount (Tons) }\end{array}$ & $\begin{array}{c}\text { Coffee Production } \\
\text { (In Thousands 60 kg Bags) }\end{array}$ \\
\hline 2014 & $10,517,049$ & 8367 & $8,800,137$ & 154,066 \\
2015 & $10,951,718$ & 8102 & $8,872,748$ & 148,559 \\
2016 & $10,951,718$ & 8594 & $9,319,855$ & 153,561 \\
2017 & $10,840,130$ & 8498 & $9,212,169$ & 159,047 \\
\hline
\end{tabular}

As shown above, the coffee industry contributes to the global market a great deal. Unfortunately, the inevitable result of such large-scale coffee production generates large quantities of agriculture residuals (in liquid and solid form), which results in serious environmental pollution. Those are produced mainly during the treatment of the coffee beans (coffee cherries skin, pulp, husk), as well as the coffee beverage preparation itself, specifically, a spent coffee ground (SCG) [4,5].

SCG can be generated in small-scale within the individuals or small gastronomy units, but also on a large-scale within the manufactories of the coffee industry. Reports displayed that $1 \mathrm{~kg}$ of produced coffee beans in a large-scale industry offers approximately $400 \mathrm{~g}$ of instant coffee and the rest of the material (600 g) represents the SCG [8]. Fortunately, large-scale manufactories have developed awareness about waste management of their own residues, invest into residues subsequent reusing, thus, adapt the functioning of the manufactory processes within such an idea. Knowledge about proper waste management leads to the awareness, that the residues are not waste materials but raw commodity which can be valorized and can cause manufactory's economical increase within the fuel and energy production issue [5].

Focused on the SCG, its subsequent reusing within the environmental life cycle (small-scale production) or within the economic savings as a replacement of purchased fuel (large-scale production) represent its specific treatment. Prior investigations have proven the SCGs contain specific degradable organic materials that are hardly efficient. Such degradation results in the consummation of a great amount of oxygen. Thus, it is highly inadequate to discharge it into landfills due to its putrefaction $[9,10]$. Such knowledge also supports the idea of SCG sustainable treatment necessity within the proper waste management issue.

Previous studies have reported several suitable treatment methods of SCG within its subsequent purpose utilization. SCG can be converted into biofuels of different forms (liquid, solid, gaseous) as biodiesel, bioether, biochar, bio-oil, or biogas by using of advanced biotechnological and chemical treatment processes [11,12]. Its utilization for production of other value-added products, such as $\mathrm{H}_{2}$ or ethanol, was also reported with satisfactory results due to its high content of residual oil (approximately 15\%) [13,14]. Moreover, SCG is a valuable resource of fatty acids, polyphenols, amino acids, polysaccharides and minerals suitable for further utilization [15]. Several studies also dealt with the suitability of SCG as an animal feed. Nevertheless, regarding its high content of residual oil, caffeine, and lignin (approximately 25\%) such investigations did not prove suitable results $[5,8,14,16-19]$.

SCG can compete with other agro-industrial residues while used as a heating fuel in the industrial boilers due to its high heating potential related to its high content of residual oil $[20,21]$. On the 
contrary, the combustion suitability of SCG was discussed by other authors because of its negative effect on the air quality [22].

Within the solid biofuel production, the high content of lignin in SCG indicates its advantage within the densification process because lignin is a natural binder. Such an advantage was investigated in research focused on the production of pellets from SCG mixed with wood sawdust $[14,23,24]$.

Regarding the available literature review, the main aim of performed investigations was to state the suitability of SCG to produce bio-briquette fuel in large-scale within its sustainable and environmentally friendly valorization. The investigation using high-pressure briquetting press simulates the large-scale production of bio-briquette fuel in the commercial sector and reflects the practice. Investigation using SCG and commercial conditions of bio-briquette fuel production is nowadays missing. To achieve such a major aim, several minor aims were developed. Primarily, a chemical analysis of SCG was investigated to determine its suitability for the process of direct combustion and energy generation. Secondary, the SCG was used as a feedstock material to produce solid biofuels, specifically, of bio-briquettes. Within the SCG solid biofuel production issue, two main topics were investigated:

1. How does SCG influence the energy potential of produced bio-briquette samples?

2. How does SCG influence the mechanical quality of produced bio-briquette samples?

\section{Materials and Methods}

The present chapter describes all characteristics of performed research. It starts with the investigated waste materials, their origin and parameters, followed by the description of used chemical experimental measurements, up to the bio-briquette samples production and testing procedures.

\subsection{Investigated Materials}

Even though present research was focused mainly on the utilization of SCG (sample A), two other waste materials were also investigated, i.e., larch sawdust (sample B) and spruce shavings (sample C). Extension of research by those two materials was performed as a response to the inconveniences caused by SCG behavior during the densification process (bio-briquette production), which are explained in the further sub-chapter "Bio-briquette samples".

The initial form of chosen materials before experimental measurements in their initial unprocessed form is expressed in Figure 1.

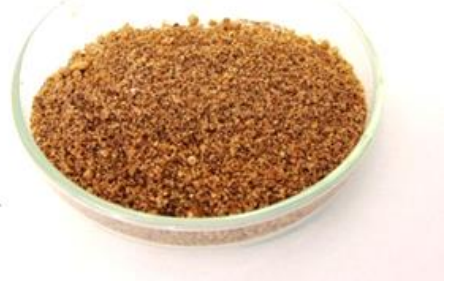

(a)

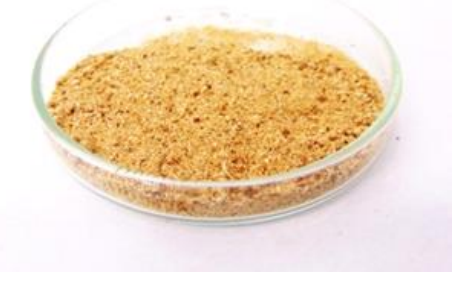

(b)

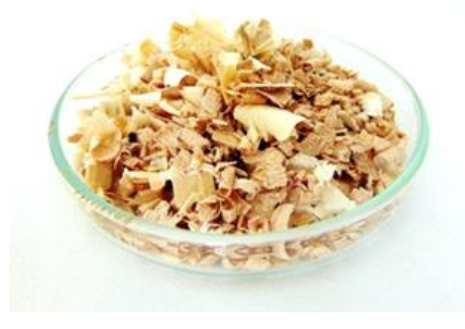

(c)

Figure 1. Feedstock samples: (a) spent coffee ground (sample A); (b) larch sawdust (sample B); (c) spruce shavings (sample C).

A microscopic analysis of particle size and shape of chosen materials was investigated within their visible disparity, which in practice results in the heterogeneity of the further created mixtures. Measurements were performed by using the stereoscopic microscope Arsenal, Type 347 SZP 11-T Zoom (Prague, Czech Republic) with a measurement scale of $1 \mathrm{~mm}$ and $5 \mathrm{~mm}$; the image analysis is visible in Figure 2. 


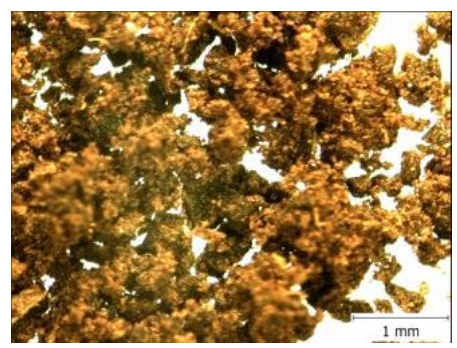

(a)

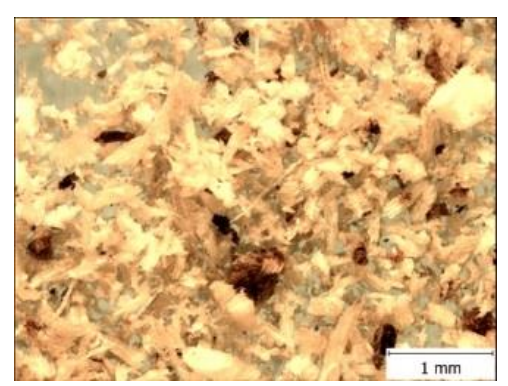

(b)

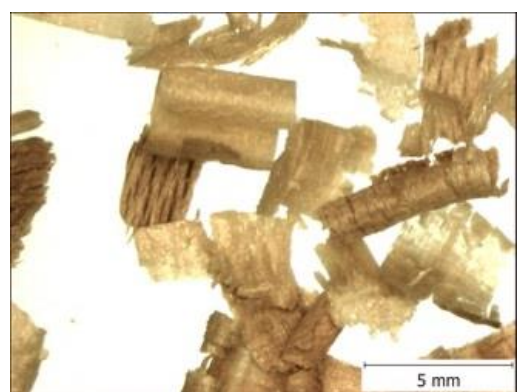

(c)

Figure 2. Microscopic analysis of feedstock samples: (a) coffee ground; (b) larch sawdust; (c) spruce shavings.

Worth to be mentioned, that all materials occurred in a form suitable for the densification process regarding their particle size, thus, the milling or crushing processes were not required. It represents a great advantage due to the reduction of electricity demands of such bio-briquette fuel production. On the contrary, the drying process was necessary.

\subsection{Fuel Parameters}

Chemical composition and energy potential of investigated materials represent important information within the statement of their suitability for energy generation by the process of direct combustion or possibly, fora different sustainable purpose (as was mentioned in the "Introduction" chapter). In total, three different waste materials were subjected to a set of tests, namely, two kinds of wood waste biomass-larch sawdust (sample B) and spruce shavings (sample C) and spent coffee ground (sample A), which represents fruit waste biomass.

The set of performed experimental measurements contained a determination of moisture content $M c(\%)$ and ash content $A c(\%)$ by using thermogravimetric analyzer LECO, type TGA 701 (Saint Joseph, United States). Further, the determination of gross calorific value GCV (MJ. $\mathrm{kg}^{-1}$ ) by using of isoperibol calorimeter LECO, type AC 600 (Saint Joseph, United States) was performed, while result values of net calorific value $\mathrm{NCV}\left(\mathrm{MJ} \cdot \mathrm{kg}^{-1}\right)$ were calculated. Finally, the results of elementary composition as Carbon $C(\%)$, Hydrogen $H(\%)$, Nitrogen $N(\%)$ were carried out by laboratory instrument LECO, type CHN628 + S (Saint Joseph, United States), which uses helium as a carrier gas. The content of Oxygen $O(\%)$ was expressed as a difference from the total sum of previously measured elements and ash (in a dry state). All measurements were repeated until the difference between observed results values correspond to the requirements of the standard. The methodology of performed experimental measurements fully followed the instructions of applied mandatory technical standards, see Table 2 .

Table 2. List of used standards within material samples chemical composition.

\begin{tabular}{clc}
\hline Number & \multicolumn{1}{c}{ Name } & Year \\
\hline EN ISO 18125 & Solid Biofuels-Determination of Calorific Value & 2017 \\
EN ISO 16948 & Solid Biofuels-Determination of Total Content of Carbon, Hydrogen and Nitrogen & 2016 \\
ISO 18122 & Solid Biofuels-Determination of Ash Content & 2015 \\
EN 18134-2 & $\begin{array}{l}\text { Solid Biofuels-Determination of Moisture Content-Oven Dry Method-Part 2: } \\
\text { Total Moisture-Simplified Method }\end{array}$ & 2015 \\
ISO 1928 & $\begin{array}{l}\text { Solid Mineral Fuels-Determination of Gross Calorific Value by the Bomb } \\
\text { Calorimetric Method, and Calculation of Net Calorific Value }\end{array}$ & 2010 \\
\hline
\end{tabular}




\subsection{Bio-Briquette Samples Production}

After performed chemical analysis the investigated materials were used as a feedstock for bio-briquette fuel production. Primarily, the materials were compared with the requirements on the feedstock materials for solid biofuel production, specific standards are noted in Table 3.

Table 3. List of used standards within feedstock materials requirements.

\begin{tabular}{clc}
\hline Number & \multicolumn{1}{c}{ Name } & Year \\
\hline EN ISO 17225-1 & Solid Biofuels-Fuel Specifications and Classes_Part 1: General Requirements & 2015 \\
EN ISO 16559 & Solid Biofuels-Terminology, Definitions and Descriptions & 2014 \\
\hline
\end{tabular}

Secondary, when the materials were evaluated as a suitable feedstock (waste biomass) for solid biofuel production, they were used for the actual densification process. For bio-briquette samples production a high-pressure hydraulic briquetting press Briklis, type BrikStar 30-12 (shown in Figure 3) (Malšice city, Czech Republic) was used, which works with a piston as a pressing unit. Used briquetting press operates automatically, thus, ensures similar bulk density $\varrho\left(\mathrm{kg} \cdot \mathrm{m}^{-3}\right)$ of produced bio-briquette samples. Produced bio-briquette samples were cylindrically shaped with diameters of $50 \mathrm{~mm}$ due to the shape and size of briquetting press die matrix.

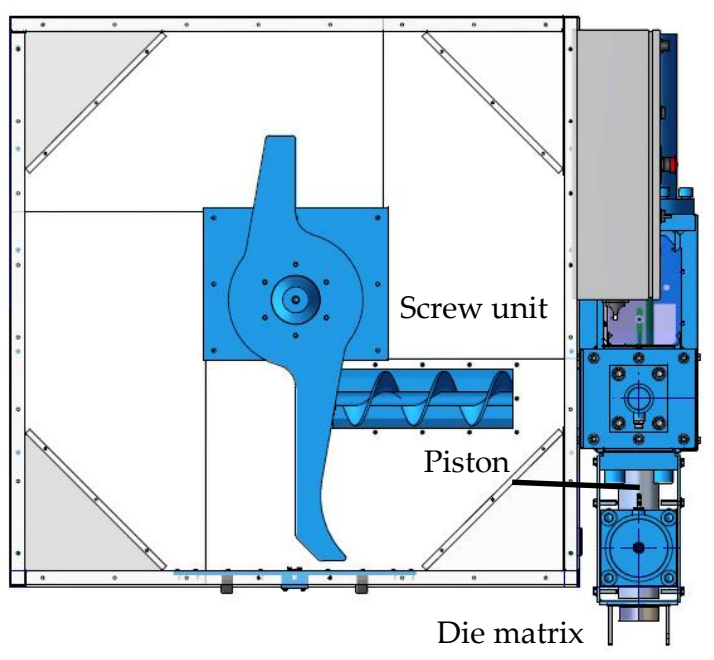

(a)

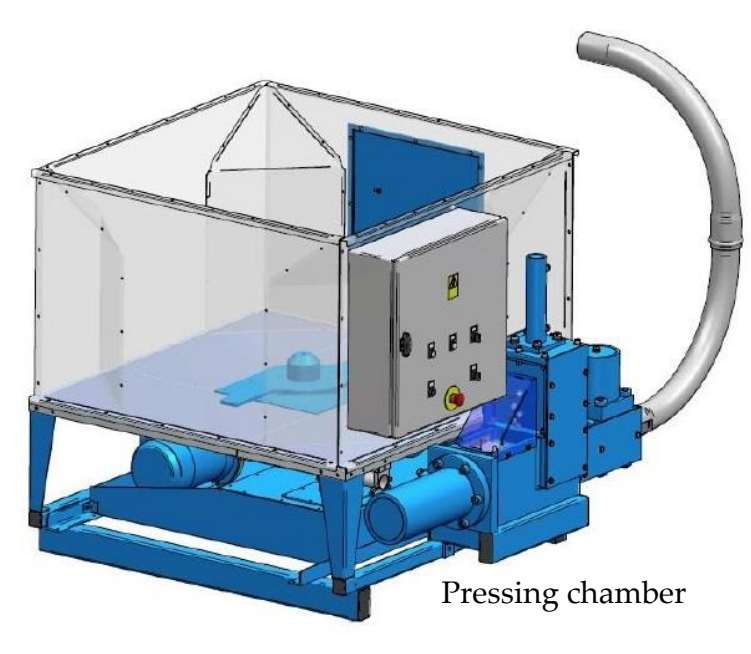

(b)

Figure 3. Scheme of used high-pressure hydraulic briquetting press: (a) top view; (b) side view.

A technical specification of used briquetting press is noted in Table 4 within the better understanding of the impact of such equipment use for bio-briquette in large-scale commercial production.

In the first step, $100 \%$ A sample (see Table 4) was used as a feedstock. Further, larch sawdust and spruce shavings have been involved in the investigation and been mixed with the SCG in different mass ratios $(1: 1,3: 1)$ to avoid another unsuccessful experiment. Created mixtures represented mixed biomass when one of the materials should be considered as an additive. Using additives within the mixed biomass bio-briquette fuel is common practice to increase specific parameters or properties. In the present case, the wood biomass was used to improve the unsuitable behavior of SCG during the densification process. Specifically created mixtures of feedstock materials are described in Table 5. 
Table 4. Technical and basic specifications of used briquetting press.

\begin{tabular}{cc}
\hline Parameter & Specification \\
\hline Operation pressure & $80-100 \mathrm{MPa}$ \\
Pressing chamber & Cylindrical \\
Pressing unit & Piston \\
Power & Electricity \\
Power consumption & $4.4 \mathrm{~kW}$ \\
Size & $2.91 \mathrm{~m}^{3}$ \\
Weight & $780 \mathrm{~kg}$ \\
Productivity & $30 \mathrm{~kg} \cdot \mathrm{h}^{-1}$ \\
Bio-briquette shape & Cylindrical \\
Bio-briquette diameter & $50 \mathrm{~mm}$ \\
\hline
\end{tabular}

Table 5. Description and identification of feedstock materials mixture types.

\begin{tabular}{ccc}
\hline Mixture Types & Mass Ratio & Identification \\
\hline Spent coffee ground & Pure & $100 \% \mathrm{~A}$ \\
Larch sawdust & Pure & $100 \% \mathrm{~B}$ \\
Spent coffee ground + larch sawdust & $1: 1$ & $50 \% \mathrm{~A}+50 \% \mathrm{~B}$ \\
Spent coffee ground + larch sawdust & $1: 3$ & $25 \% \mathrm{~A}+75 \% \mathrm{~B}$ \\
Spruce shavings & Pure & $100 \% \mathrm{C}$ \\
Spent coffee ground + spruce shavings & $1: 1$ & $50 \% \mathrm{~A}+50 \% \mathrm{C}$ \\
Spent coffee ground + spruce shavings & $1: 3$ & $25 \% \mathrm{~A}+75 \% \mathrm{C}$ \\
\hline
\end{tabular}

All created mixtures were successfully used for bio-briquette samples production. Six different types which are expressed in Figure 4 were produced.

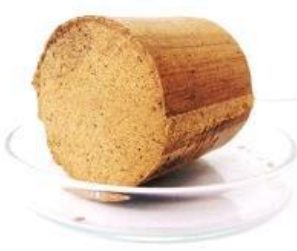

(a)

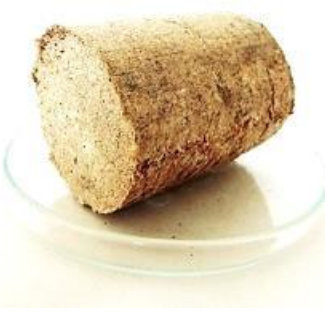

(d)

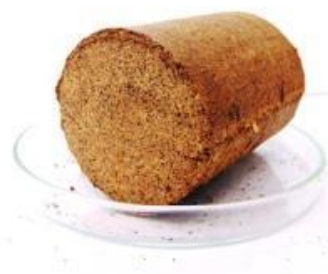

(b)

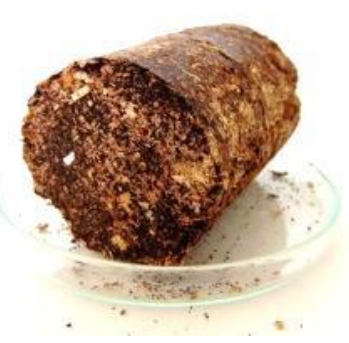

(e)

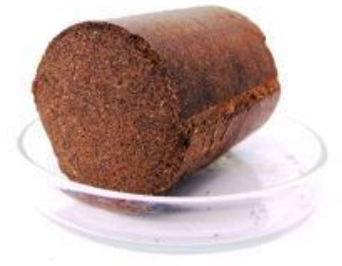

(c)

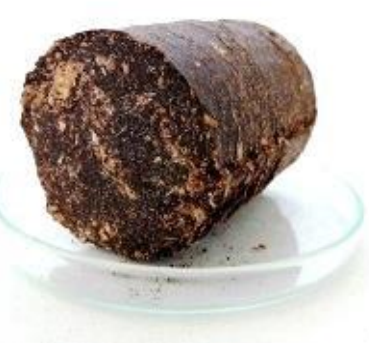

(f)

Figure 4. Produced bio-briquette samples: (a) $100 \%$ B, (b) $25 \%$ A + 75\% B, (c) $50 \%$ A + 50\% B, (d) $100 \%$ C, (e) $25 \% \mathrm{~A}+75 \% \mathrm{C}$, (f) $50 \% \mathrm{~A}+50 \% \mathrm{C}$.

All bio-briquette samples were produced with the same diameter (approximately $50 \mathrm{~mm}$ ), but their length and weight differed. After measurements of all sample dimensions, the average values were calculated and are noted in Table 6. 
Table 6. Basic technical parameters of produced bio-briquette samples (in wet basis).

\begin{tabular}{ccc}
\hline $\boldsymbol{m}(\mathrm{g})$ & $\boldsymbol{h}(\mathbf{m m})$ & $\varnothing(\mathbf{m m})$ \\
\hline $113.76 \pm 14.39$ & $53.94 \pm 4.19$ & $50.51 \pm 0.20$ \\
$(\mathrm{~g})$ & $h(\mathrm{~mm})$ & $\varnothing(\mathrm{mm})$ \\
\hline Notes: $m$-samples weight, $h$-samples height, $\varnothing$-samples diameter, \pm -standard deviation.
\end{tabular}

\subsection{Mechanical Quality Indicators}

After measurements of basic parameters were bio-briquette samples subjected to the determination of their mechanical quality. Specific indicators were experimentally tested within the statement of the type of bio-briquette samples with the highest mechanical quality. Experimental measurements were performed within the evaluation of the final mechanical quality of investigated bio-briquette samples and the procedures corresponded to the related standards (see Table 7) or were based on knowledge from practice.

Table 7. List of used standards within bio-briquette samples quality testing.

\begin{tabular}{clc}
\hline Number & \multicolumn{1}{c}{ Name } & Year \\
\hline EN 15234-1 & Solid Biofuels-Fuel Quality Assurance-Part 1: General Requirements & 2011 \\
EN ISO 17831-2 & $\begin{array}{l}\text { Solid Biofuels-Determination of Mechanical Durability of Pellets and } \\
\text { Briquettes-Part 2: Briquettes }\end{array}$ & 2015 \\
\hline
\end{tabular}

Basic dimension parameters of produced bio-briquette samples were used for the calculation of the first important mechanical quality indicator, a Bulk density $\varrho\left(\mathrm{kg} \cdot \mathrm{m}^{-3}\right)$. Such an indicator describes the ability and suitability of the material for the densification process and resulting in the final quality of products. Following formula was used within performed calculations:

$$
\rho=\frac{m}{V}
$$

$\rho$-volume density $\left(\mathrm{kg} \cdot \mathrm{m}^{-3}\right), m$-bio-briquette samples mass $(\mathrm{kg}), V$-bio-briquette samples volume $\left(\mathrm{m}^{3}\right)$.

As an important indicator of bio-briquette fuel mechanical quality within the commercial biofuel sale is considered a Mechanical durability $D U(\%)$; such an indicator describes the mechanical strength and ability of the bio-briquette fuel to resists the impacts during the handling, transportation or storage. Within the experimental testing were bio-briquette samples subjected to controlled impacts inside of the special electric rotating dust-proof drum equipped with a rectangular steel partition, see Figure 5.

Before and after experimental testing where all samples weighted and final loss of material (abrasion) was calculated by using of following formula:

$$
D U=\frac{m_{a}}{m_{e}} \cdot 100
$$

$D U$-mechanical durability (\%), $m_{a}$-samples weight after testing $(\mathrm{g}), m_{e}$-samples weight before testing $(\mathrm{g})$.

To simulate the stress of the bio-briquette fuel in practice, the mechanical indicator of Compressive strength $\sigma\left(\mathrm{N} \cdot \mathrm{mm}^{-1}\right)$ was applied. Such an indicator did not correspond to any technical standards but is based on previously published papers about strength of products under the pressure [25-28]. Such an indicator plays an important role in the logistics of solid biofuel transportation and storage when bio-briquette fuel is stored above each other. Basically, a maximum increasing load, which can tested bio-briquette sample absorbs before it disintegrates, was measured [29]. Experimental measurements were performed by using a universal testing machine Labortech, type MP Test 5.050 (Opava, Czech Republic) with force meter KAF-S (range of 0-5000 N, used accuracy 0.1 N). After experimental deformation measurement of maximal load $F_{\max }(\mathrm{N})$ were used in the following formula to calculate the result values of Compressive strength $\sigma\left(\mathrm{N} \cdot \mathrm{mm}^{-1}\right)$ : 


$$
\sigma=\frac{F_{\max }}{L}
$$

$\sigma$-compressive strength in cleft $\left(\mathrm{N} \cdot \mathrm{mm}^{-1}\right), F_{\max }$-maximal load $(\mathrm{N}), L$-bio-briquette sample length $(\mathrm{m})$.

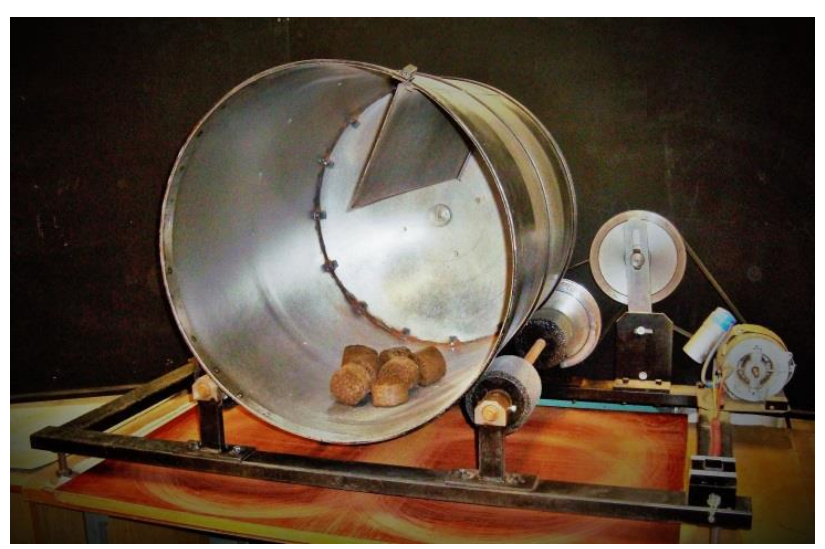

(a)

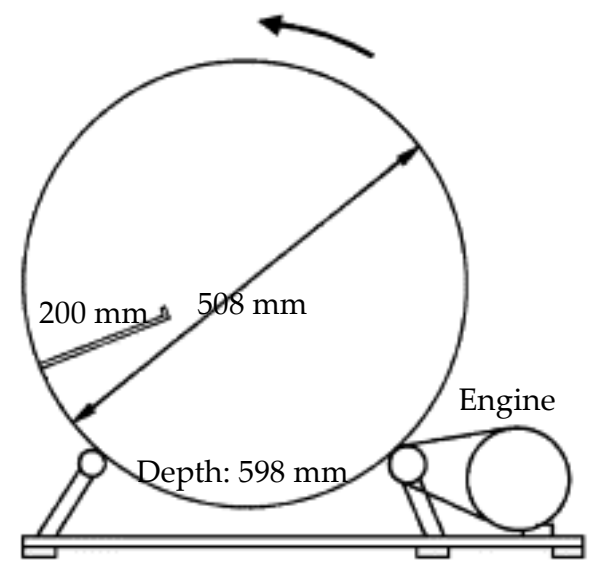

(b)

Figure 5. Equipment for mechanical durability $D U$ (\%) testing: (a) in use; (b) scheme.

\section{Results and Discussion}

Present result data corresponds to the investigated issues of feedstock materials parameters and bio-briquette samples quality; consequently, the current chapter is divided in such order as well.

\subsection{Fuel Parameters}

The first evaluated indicators should primarily describe the suitability of SCG for direct combustion processes within the bio-briquette fuel burning. As Table 8 below describes, the results of the basic chemical parameters of investigated samples were obtained, in both, wet basis and dry basis.

Table 8. Analysis of samples fuel parameters and energy potential (in w.b.).

\begin{tabular}{|c|c|c|c|c|}
\hline Biomass Sample & $M c(\%)$ & $A c(\%)$ & $G C V\left(\mathrm{MJ} \cdot \mathrm{kg}^{-1}\right)$ & $N C V\left(\mathbf{M J} \cdot \mathbf{k g}^{-1}\right)$ \\
\hline $100 \% \mathrm{~A}$ & $9.56 \pm 0.15$ & $1.49 \pm 0.06$ & $21.58 \pm 0: 04$ & 19.96 \\
\hline $100 \% \mathrm{~B}$ & $14.36 \pm 0.15$ & $0.43 \pm 0.73$ & $17.86 \pm 0.03$ & 16.42 \\
\hline $100 \% \mathrm{C}$ & $8.25 \pm 0.01$ & $0.31 \pm 0.16$ & $18.68 \pm 0: 01$ & 17.27 \\
\hline
\end{tabular}

Notes: w.b.-wet basis, $M c$-moisture content, $A c$-ash content, GCV-gross calorific value, $N C V$-net calorific value.

Samples moisture content $M c(\%)$ was stated as a first; results of all samples occurred at a higher level than it is recommended for the bio-briquette fuel production, but the level was still acceptable. Moisture content $M c(\%)$ of properly prepared feedstock material should not exceed $15 \%$. A higher level of moisture content $M c(\%)$ should be considered as a limitation because it results in a lower amount of produced energy (more energy is consumed for vaporizing of moisture during the fuel burning) [30,31]. Nevertheless, such an indicator can be easily improved by the feedstock drying process. Further, an energy potential of samples expressed as a calorific values $C V\left(\mathrm{MJ} \cdot \mathrm{kg}^{-1}\right)$ was investigated. As is visible, calorific value $C V\left(\mathrm{MJ} \cdot \mathrm{kg}^{-1}\right.$ ) of wood biomass samples occurred at a satisfactory level, typical for wood biomass according to the technical standard EN ISO 17225-1 (2015): Solid Biofuels - Fuel Specifications and Classes-Part 1: General Requirements. On the contrary, desired SCG proved an extremely high level of calorific values $C V\left(\mathrm{MJ} \cdot \mathrm{kg}^{-1}\right)$, which indicated a high potential in energy generation by using combustion processes. Moreover, if the level of moisture content $M c$ (\%) occurred 
at lower level, the results of calorific values $C V\left(\mathrm{MJ} \cdot \mathrm{kg}^{-1}\right)$ would be even better. Such a positive result was amplified by the observed low level of ash content $A c(\%)$, which is highly appreciated because it indicates the positive behavior of fuel during burning. Moreover, observed ash content Ac (\%) was comparable with the ash contents $A c$ (\%) of wood biomass samples, which commonly occurred at low level, but other biomass kinds (herbaceous, fruit, aquatic, mixed) commonly express worst results. Thus, the combination of a high level of calorific values $C V\left(\mathrm{MJ} \cdot \mathrm{kg}^{-1}\right)$ and low level of ash content $A c$ (\%) was evaluated as a significant advantage of SCG samples.

In consequence, SCG represents high-quality feedstock material for bio-briquette production, as well as to produce other types of biofuel intended for energy generation by burning. It indicates that SCG can be used as an additive or as one of feedstock in specific feedstock mixtures within increasing of final mixture calorific value. Such an idea was already investigated in a case of a mixture of SCG with herbaceous biomass (wheat straw) with satisfactory results [32]. As was reported in a different study, addition of SCG in amount of $10 \%$ and $25 \%$ to beech wood biomass feedstock increased the calorific value $C V$ of final products from initial $18.77 \mathrm{MJ} \cdot \mathrm{kg}^{-1}$ to $19.12 \mathrm{MJ} \cdot \mathrm{kg}^{-1}(10 \%$ of SCG) and $20.32 \mathrm{MJ} \cdot \mathrm{kg}^{-1}$ (10\% of SCG) [33].

For comparison of observed result values with other author's results (sorted from the best result to the worst) were inserted in Table 9 below.

Table 9. Comparison of SCG basic chemical parameters.

\begin{tabular}{ccc}
\hline Indicator & Result & Reference \\
\hline & 2.43 & {$[24]$} \\
Ash content $A c(\%)$ & 2.06 & {$[20]$} \\
& 1.60 & {$[34]$} \\
& 1.43 & {$[35]$} \\
& 1.07 & {$[33]$} \\
\hline Calorific value $C V$ & 19.30 & {$[35]$} \\
$\left(\mathrm{MJ}^{-1} \mathrm{~kg}^{-1}\right)$ & 21.60 & {$[23]$} \\
& 22.89 & {$[32]$} \\
& $23.72-24.07$ & {$[36]$} \\
& 26.00 & {$[37]$} \\
\hline
\end{tabular}

The observed high level of calorific value $C V\left(\mathrm{MJ} \cdot \mathrm{kg}^{-1}\right)$ could be caused by the presence of residual oil in the SCG. As the literature reports, the content of residual oil in SCG occurs at the following levels: $13.0 \%$ [38], 14.7\% [34], 28.3\%. Moreover, the calorific value CV (MJ.kg-1) of SCG residual oil occurred at an extremely high level, specifically $36.4 \mathrm{MJ} \cdot \mathrm{kg}^{-1}$ [35]. The elementary composition analyses (expressed in Table 10) proved low levels of Oxygen $O(\%)$ in the case of SCG, which is required. Result values of both wood biomass materials occurred at a satisfactory level as well; Oxygen O (\%) level should occurred around $40 \%$.

Table 10. Analysis of elementary composition in dry basis (in d.b.).

\begin{tabular}{ccccc}
\hline $\begin{array}{c}\text { Biomass } \\
\text { Sample }\end{array}$ & $\boldsymbol{C ~ ( \% )}$ & $\boldsymbol{H ~ ( \% )}$ & $\boldsymbol{N ~ ( \% )}$ & $\boldsymbol{O} \mathbf{( \% )}$ \\
\hline $100 \%$ A & 55.49 & 7.07 & 2.38 & 33.41 \\
$100 \%$ B & 49.76 & 6.12 & 0.10 & 42.38 \\
$100 \%$ C & 51.08 & 6.06 & 0.04 & 42.48 \\
\hline
\end{tabular}

Notes: C-Carbon, $\mathrm{H}$-Hydrogen, $\mathrm{N}$-Nitrogen, O-Oxygen.

To compare observed data of elementary composition, Table 11 was prepared; noted data originates from other authors' studies and except one value of Nitrogen $N(\%)$ (highlighted by bold letters) all values occurred at a similar level as the result value of the present research. 
Table 11. Literature review of elementary composition of SCG.

\begin{tabular}{ccccc}
\hline $\mathbf{C ~ ( \% )}$ & $\mathbf{H ~ ( \% )}$ & $\mathbf{N ~ ( \% )}$ & $\mathbf{O}(\%)$ & Reference \\
\hline 48.67 & 6.54 & 2.27 & 40.03 & {$[24]$} \\
52.20 & - & 2.10 & - & {$[35]$} \\
52.50 & 7.00 & 3.46 & 34.80 & {$[39]$} \\
53.00 & 6.80 & 2.10 & 38.10 & {$[34]$} \\
46.42 & 6.04 & $\mathbf{1 5 . 5 0}$ & - & {$[38]$} \\
58.50 & 7.40 & 1.30 & - & {$[37]$} \\
53.05 & 7.19 & 1.45 & 36.20 & {$[20]$} \\
\hline
\end{tabular}

Notes: C-Carbon, $\mathrm{H}$-Hydrogen, $\mathrm{N}$-Nitrogen, O-Oxygen.

For a more detailed evaluation of investigated materials chemical analyses where the results were also determined in a dry ash free state, see Table 12, which expresses them in the most exact way. Within this state, the results are expressed without the presence of ash, which can occasionally influence the final result values. Such an influence can be caused by the contamination of samples by dust or external impurities.

Table 12. Analysis of elementary composition and energy potential in a dry ash free state (d.a.f.).

\begin{tabular}{|c|c|c|c|c|c|c|}
\hline Biomass Sample & $C(\%)$ & $H(\%)$ & $N(\%)$ & $O(\%)$ & $G C V\left(\mathrm{MJ} \cdot \mathrm{kg}^{-1}\right)$ & $N C V\left(\mathrm{MJ} \cdot \mathrm{kg}^{-1}\right)$ \\
\hline $100 \% \mathrm{~A}$ & 56.42 & 7.19 & 2.42 & 33.97 & 24.27 & 22.71 \\
\hline $100 \% \mathrm{~B}$ & 50.59 & 6.22 & 0.10 & 43.09 & 20.08 & 18.72 \\
\hline $100 \% \mathrm{C}$ & 51.26 & 6.08 & 0.04 & 42.62 & 20.43 & 19.11 \\
\hline
\end{tabular}

Notes: C-Carbon, $\mathrm{H}$-Hydrogen, $\mathrm{N}$-Nitrogen, $\mathrm{O}$-Oxygen, $\mathrm{GCV}$-gross calorific value, $\mathrm{NCV}$-net calorific value.

\subsection{Mechanical Quality}

The first practical result, which was observed, was the inability of production of bio-briquette samples from pure SCG, thus, it was concluded that such production is not feasible. Moreover, related to the complications monitored during the briquetting press work, it was not recommended to continue in the procedure due to the high possibility of briquetting press damages. Before such a statement, it must be highlighted that the SCGs were properly prepared for the densification process and fulfilled all requirements (suitable moisture content and particle size), thus, the difficulties were related directly to the characteristics of SCG itself as a reported high content of residual oil.

The second observed result was related to the visual conditions of produced bio-briquette samples. As visible from Figure 6 the homogeneity of samples (as well as feedstock mixture) achieved better results in the case of the $A+B$ mixtures. Such a result was related to the similarity of their particle size. In the case of the $\mathrm{A}+\mathrm{C}$ mixtures was concluded that the difference in the particle sizes was too significant, thus, the particles could not establish permanent and strong bonds between each other. Such a statement was supported by the observation of particle bonds breaking directly after the bio-briquette samples production, which was reflected as a material loss during sample handling.

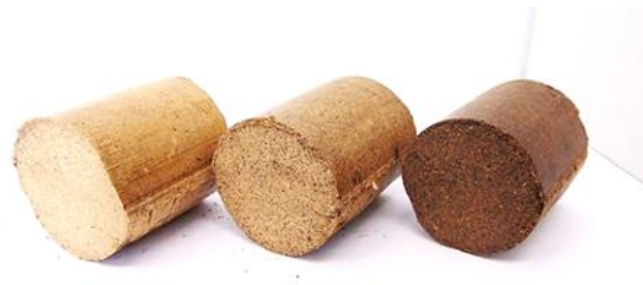

(a)

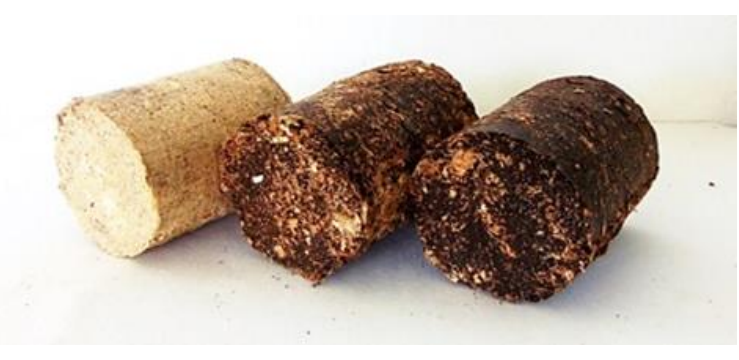

(b)

Figure 6. Visual comparison of produced bio-briquette samples: (a) A + B mixtures; (b) A + C mixtures. 
If compare results of tested mechanical quality indicators, all of them proved the higher mechanical quality of bio-briquette samples produced from A + B mixtures. First monitored (calculated) indicator, the bulk density $\rho\left(\mathrm{kg} \cdot \mathrm{m}^{-3}\right)$, proved a satisfactory level of all produced bio-briquette samples if compared with the requirements for commercial sale; $\rho$ should range between $900-1200 \mathrm{~kg} \cdot \mathrm{m}^{-3}$ [37-39]. Observed data noted in Table 13 provide a clear comparison between all tested bio-briquette samples, while Table 13 provides a comparison between bulk densities $\rho\left(\mathrm{kg} \cdot \mathrm{m}^{-3}\right)$ of bio-briquette fuel produced from different feedstock materials.

Table 13. Mechanical quality indicators of investigated bio-briquette samples.

\begin{tabular}{|c|c|c|c|c|}
\hline Biomass Sample & $M c(\%)$ & $\begin{array}{c}\rho \\
\left(\mathrm{kg} \cdot \mathrm{m}^{-3}\right)\end{array}$ & $D U(\%)$ & $\begin{array}{c}\sigma \\
\left(\mathbf{N} \cdot \mathbf{m m}^{-1}\right)\end{array}$ \\
\hline $100 \% \mathrm{~A}$ & - & - & - & - \\
\hline $100 \%$ B & $13.14 \pm 0.68$ & $1026.39 \pm 27.08$ & $98.44 \pm 0.08$ & $102.78 \pm 29.78$ \\
\hline $50 \% A+50 \% B$ & $11.47 \pm 0.42$ & $1112.58 \pm 34.83$ & $90.05 \pm 1.04$ & $46.07 \pm 8.98$ \\
\hline $25 \% \mathrm{~A}+75 \% \mathrm{~B}$ & $13.47 \pm 0.17$ & $1042.39 \pm 57.86$ & $90.12 \pm 0.03$ & $50.85 \pm 11.64$ \\
\hline $100 \% \mathrm{C}$ & $9.2 \pm 0.1$ & $1036.53 \pm 24.44$ & $96.70 \pm 1.00$ & $179.48 \pm 24.43$ \\
\hline $50 \% \mathrm{~A}+50 \% \mathrm{C}$ & $9.9 \pm 0.4$ & $956.45 \pm 68.40$ & $49.00 \pm 0.38$ & $37.09 \pm 11.25$ \\
\hline $25 \% \mathrm{~A}+75 \% \mathrm{C}$ & $10.3 \pm 0.1$ & $842.42 \pm 69.99$ & $44.00 \pm 0.11$ & $31.06 \pm 8.87$ \\
\hline
\end{tabular}

Further, mechanical durability $D U(\%)$ represents the most important quality indicator of bio-briquette fuel, which indicates if the fuel is suitable for commercial production (achievement is mandatory). The lowest acceptable level of mechanical durability is $D U>90 \%$; the next level defining solid biofuel of the highest mechanical durability is $D U>95 \%$ [40]. As is visible from Table 12, the bio-briquette samples produced from A + B mixtures achieved the acceptable level and fulfilled mandatory requirements for commercial sale. Bio-briquette samples produced from $\mathrm{A}+\mathrm{C}$ mixtures exhibited results deeply below the acceptable level of DU (\%). Satisfactory results were observed only in the case of $100 \%$ C bio-briquette samples. Observed result values can be easily compared with the results of pure wood biomass feedstock samples to evaluate the influence of SCG on the final mechanical quality of samples. A comparison of investigated bio-briquette samples $D U(\%)$ with the results of other author's studies is expressed in Table 14.

Moreover, bio-briquette samples produced from A + B mixtures proved a high level of mechanical durability $D U(\%)$, despite their higher level of moisture content $M c(\%)$, which is commonly evaluated as a limitation. In general, a high level of moisture content $M c(>15 \%)$ can cause problems during the densification process or within the product's final quality.

The last investigated indicator, the compressive strength $\sigma\left(\mathrm{N} \cdot \mathrm{mm}^{-1}\right)$, monitored the ability of bio-briquette samples to resist the pressure. In practice, such ability is important during bio-briquette fuel handling and storage when the fuel is packed above each other in multiple layers. Best results were achieved by $100 \%$ B and 100\% C bio-briquette samples, which was expected. All bio-briquette samples created from feedstock mixtures exhibited worse result, but comparable within the mixture samples. The investigated bio-briquette samples after the deformation testing are expressed in Figure 7.

Compressive strength $\sigma\left(\mathrm{N} \cdot \mathrm{mm}^{-1}\right)$ of bio-briquette fuel is not stated by any mandatory standards, thus, there are no required levels to achieve. Its evaluation can be performed only by the form of comparison with similar performed measurements, see Table 14. 


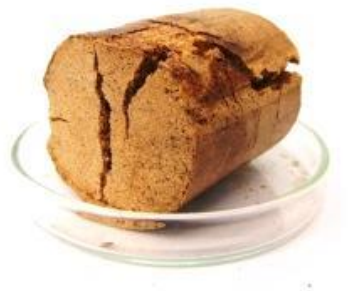

(a)

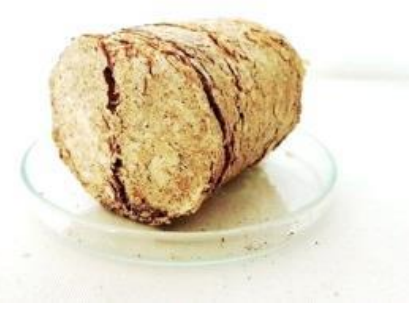

(d)

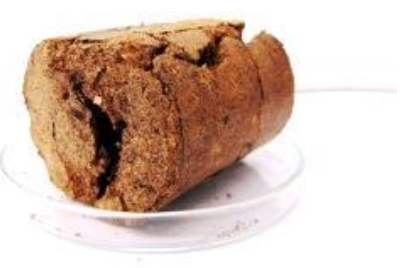

(b)

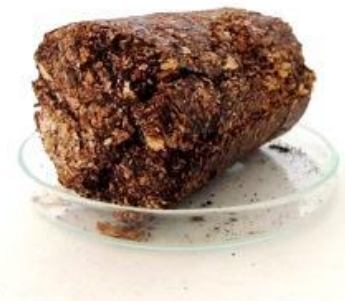

(e)

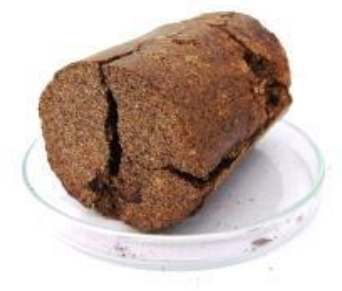

(c)

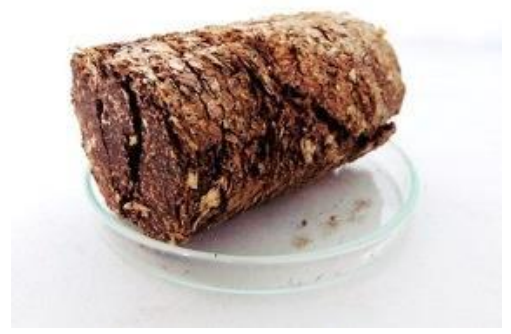

(f)

Figure 7. Bio-briquette samples after compressive strength $\sigma\left(\mathrm{N} \cdot \mathrm{mm}^{-1}\right)$ testing: (a) $100 \% \mathrm{~B},(\mathbf{b}) 25 \% \mathrm{~A}+$ $75 \% \mathrm{~B}$, (c) $50 \% \mathrm{~A}+50 \% \mathrm{~B}$, (d) $100 \% \mathrm{C}$, (e) $25 \% \mathrm{~A}+75 \% \mathrm{C}$, (f) $50 \% \mathrm{~A}+50 \% \mathrm{C}$.

Table 14. Comparison of reported bio-briquette fuel mechanical quality indicators.

\begin{tabular}{cccc}
\hline Indicator & Result & Feedstock & Reference \\
\hline & $1,110.00$ & Coffee pulp & {$[41]$} \\
Bulk density $\rho$ & 986.37 & Bamboo fiber & {$[42]$} \\
$\left(\mathrm{kg} \cdot \mathrm{m}^{-3}\right)$ & 964.00 & Cotton stalk & {$[43]$} \\
& 930.00 & Oat straw & {$[44]$} \\
& 896.34 & Jatoba sawdust & {$[45]$} \\
\hline Mechanical durability & 98.90 & Digestate & {$[46]$} \\
DU (\%) & 97.06 & Date palm stalks & {$[47]$} \\
& 91.40 & Energy crop & {$[48]$} \\
& 83.46 & Wheat straw & {$[49]$} \\
Compressive strength & 77.60 & Jatoba sawdust & {$[45]$} \\
$\sigma\left(\mathrm{N} \cdot \mathrm{mm}^{-1}\right)$ & 176.10 & Plane tree chips & {$[50]$} \\
& 112.10 & Japanese & {$[51]$} \\
& 58.73 & knotweed & {$[52]$} \\
& 47.05 & Waste paper & {$[45]$} \\
\hline
\end{tabular}

As data noted in Table 14 indicates, bio-briquette samples investigated in present research proved a satisfactory level of bulk density $\rho\left(\mathrm{kg} \cdot \mathrm{m}^{-3}\right)$, if compare with other types of bio-briquette fuel. In the case of mechanical durability $D U(\%)$ can be indicated that bio-briquette samples from $\mathrm{A}+\mathrm{B}$ mixtures and $100 \% \mathrm{C}$ material correspond to the highest level of $D U(\%)$ across different biomass bio-briquette fuel. On the contrary, it can be concluded that observed results of bio-briquette samples produced from $100 \% \mathrm{~A}$ and $\mathrm{A}+\mathrm{C}$ mixtures occurred at a very low level, even if compare with various types of other bio-briquette fuel. Finally, the compressive strength $\sigma\left(\mathrm{N} \cdot \mathrm{mm}^{-1}\right)$ comparison expressed that $100 \% \mathrm{~B}$ and $100 \% \mathrm{C}$ occurred at a satisfactory level of such indicator, while all mixed bio-briquette samples occurred at a lower level. 


\section{Conclusions}

In conclusion, performed investigations proved the suitability of SCG for processes of direct combustion within the energy production, however, proved that SCG in pure unmixed form is not usable for the briquetting process. The creation of feedstock separate mixtures of SCG with two different wood biomasses (sawdust, shaving) improved such inappropriate properties of SCG. Better mechanical quality was observed in the case of bio-briquette samples from SCG mixed with wood sawdust due to similar particle size, rather than with wood shavings. It indicates that the addition of SCG into the feedstock mixture influenced the final chemical and mechanical quality of bio-briquette samples in a very expressive way. The amount (mass ratio) of SCG in the feedstock mixtures should be stated carefully; a lower mass ratio of spent coffee ground than $1: 1$ ( $50 \%$ of SCG) or 1:3 (25\% of SCG) should be used in case of mixing with wood biomass. In conclusion, the addition of SCG improved the heating abilities of produced bio-briquette samples, however, decrease their mechanical quality. Such a negative result can be easily improved by the creation of feedstock mixtures with a different mass ratio of SCG.

Author Contributions: Conceptualization, A.B. and M.B.; methodology, A.B. and M.B.; validation, A.B. and M.B.; formal analysis, A.B. and H.R.; investigation, A.B. and M.B.; resources, A.B., H.R. and D.H.; data curation, A.B.; writing—original draft preparation, A.B.; writing—review and editing, H.R., M.B., A.H., U.H., D.A.I., D.H.; visualization, H.R.; supervision, M.B.; project administration, H.R. and D.H.; funding acquisition, H.R. and D.H.". All authors have read and agreed to the published version of the manuscript.

Funding: This research was funded by European Union (EU), managing authority of the Czech Operational Programme Research, Development and Education within the project "Supporting the development of international mobility of research staff at CULS Prague", grant number CZ.02.2.69/0.0/0.0/16_027/0008366. Further, research was supported by the Internal Grant Agency of the Czech University Life Sciences Prague, grant number 20173005 (31140/1313/3108) and by Internal Grant Agency of the Faculty of Engineering, Czech University of Life Sciences Prague, grant number 2019:31140/1312/3103.

Conflicts of Interest: The authors declare no conflict of interest.

\section{References}

1. Belitz, H.D.; Grosch, W.; Schieberle, P. Coffee, tea, cocoa. Food Chem. 2009, 938-951. [CrossRef]

2. Etienne, H. Somatic embryogenesis protocol: Coffee (Coffea arabica L. and C. canephora P.). In Protocol for Somatic Embryogenesis in Woody Plant; Springer: Dordrecht, The Netherlands, 2005; pp. 167-168. [CrossRef]

3. Grigg, D. The worlds of tea and coffee: Patterns of consumption. GeoJournal 2002, 57, 283-294. [CrossRef]

4. Nabais, J.M.V.; Nunes, P.; Carrott, P.J.M.; Carrott, M.R.; García, A.M.; Díez, M.A.D. Production of activated carbons from coffee endocarp by CO2 and steam activation. Fuel Process. Technol. 2008, 89, $262-268$. [CrossRef]

5. Mussatto, S.I.; Dragone, G.; Roberto, I.C. Brewer's spent grain: Generation, characteristics and potential applications. J. Cereal Sci. 2006, 43, 1-14. [CrossRef]

6. FAO. Food and Agriculture Organization of the United Nations. 2019. Available online: http://www.fao.org/ faostat/en/?\#data (accessed on 5 March 2019).

7. ICO. International Coffee Organization. 2010. Available online: http://www.ico.org/historical/1990\% 20onwards/PDF/1a-total-production.pdf (accessed on 5 March 2019).

8. Acevedo, F.; Rubilar, M.; Scheuermann, E.; Cancino, B.; Uquiche, E.; Garcés, M.; Inostroza, K.; Shene, C. Bioactive compounds of spent coffee grounds, a coffee industrial residue. In Proceedings of the III Symposium on 212 A.E. ATABANI ET AL. Agricultural and Agroindustrial Waste Management, Sao Pedro, Brazil, 12-14 March 2013.

9. Corro, G.; Pal, U.; Cebada, S. Enhanced biogas production from coffee pulp through deligninocellulosic photocatalytic pretreatment. Energy Sci. Eng. 2014, 2, 177-187. [CrossRef]

10. Machado, E.S.M. Reaproveitamento de Resíduos da Indústria do Café Como Matéria-Prima Para a Produção de Etanol. Master's Thesis, Department of Biological Engineering, University of Minho, Braga, Portugal, 2009.

11. Karmee, S.K. A spent coffee grounds based biorefinery for the production of biofuels, biopolymers, antioxidants and biocomposites. Waste Manag. 2018, 72, 240-254. [CrossRef] [PubMed] 
12. Gardy, J.; Rehan, M.; Hassanpour, A.; Lai, X.; Nizami, A.S. Advances in nano-catalysts based biodiesel production from non-food feedstocks. J. Environ. Manag. 2019, 249, 109316. [CrossRef]

13. Sendzikiene, E.; Makareviciene, V.; Janulis, P.; Kitrys, S. Kinetics of free fatty acids esterification with methanol in the production of biodiesel fuel. Eur. J. Lipid Sci. Technol. 2004, 106, 831-836. [CrossRef]

14. Kondamudi, N.; Mohapatra, S.K.; Misra, M. Spent coffee grounds as a versatile source of green energy. J. Agric. Food Chem. 2008, 56, 11757-11760. [CrossRef]

15. Zabaniotou, A.; Kamaterou, P. Food waste valorization advocating Circular Bioeconomy-A critical review of potentialities and perspectives of spent coffee grounds biorefinery. J. Clean. Prod. 2019, 211, 1553-1566. [CrossRef]

16. Ballesteros, L.; Teixeira, J.; Mussato, S. Chemical, functional, and structural properities of spent coffee grounds and coffee silverskin. Food Bioprocess Technol. 2014, 7, 3493-3503. [CrossRef]

17. Claude, B. Étude bibliographique: Utilisation dês sous-produits du café. Café Cacao Thé 1979, 23, $146-152$.

18. Givens, D.I.; Barber, W.P. In vivo evaluation of spent coffee grounds as a ruminant feed. Agric. Wastes 1986, 18, 69-72. [CrossRef]

19. Cruz, G.M. Resíduos de cultura e indústria. Inf. Agropecuário 1983, 9, 32-37.

20. Kang, S.B.; Oh, H.Y.; Kim, J.J.; Choi, K.S. Characteristics of spent coffee ground as a fuel and combustion test in a small boiler $(6.5 \mathrm{~kW})$. Renew. Energy 2017, 113, 1208-1214. [CrossRef]

21. Silva, M.A.; Nebra, S.A.; Machado Silva, M.J.; Sanchez, C.G. The use of biomass residues in the Brazilian soluble coffee industry. Biomass Bioenergy 1998, 14, 457-467. [CrossRef]

22. ABNT. Associação Brasileira de Normas Técnicas, Resíduos Sólidos-Classificação-NBR 10.004; ABNT: Rio de Janeiro, Brazil, 1987. Available online: https://analiticaqmcresiduos.paginas.ufsc.br/files/2014/07/Nbr-100042004-Classificacao-De-Residuos-Solidos.pdf (accessed on 5 August 2019).

23. Haile, M. Integrated volarization of spent coffee grounds to biofuels. Biofuel Res. J. 2014, 2, 65-69. [CrossRef]

24. Allesina, G.; Pedrazzi, S.; Allegretti, F.; Tartarini, P. Spent coffee grounds as heat source for coffee roasting plants: Experimental validation and case study. Appl. Therm. Eng. 2017, 126, 730-736. [CrossRef]

25. Okot, D.K.; Bilsborrow, P.E.; Phan, A.N. Effects of operating parameters on maize COB briquette quality. Biomass Bioenergy 2018, 112, 61-72. [CrossRef]

26. Seifi, M.R. The moisture content effect on some Physical and Mechanical Properties of Corn. J. Agric. Sci. 2010, 2, 125-134. [CrossRef]

27. Altuntaş, E.; Yıldız, M. Effect of moisture content on some physical and mechanical properties of faba bean (Vicia faba L.) Grains. J. Food Eng. 2007, 78, 174-183. [CrossRef]

28. Yahya, A.; Hamdan, K.; Ishola, T.A.; Suryanto, H. Physical and mechanical properties of Jatropha curcas L. fruits from different planting densities. J. Appl. Sci. 2013, 13, 1004-1012. [CrossRef]

29. Rubio, B.; Izquierdo, M.T.; Segura, E. Effect of binder addition on the mechanical and physicochemical properties of low rank coal char briquettes. Carbon 1999, 37, 1833-1841. [CrossRef]

30. Hu, J.; Yu, F.; Lu, Y. Application of Fischer-Tropsch synthesis in biomass to liquid conversion. Catalysts 2012, 2, 303-326. [CrossRef]

31. Din, Z.D.; Zainal, Z.A. Biomass integrated gasification-SOFC systems: Technology overview. Renew. Sustain. Energy Rev. 2016, 53, 1356-1376. [CrossRef]

32. Sołowiej, P.; Neugebauer, M. Impact of coffee grounds addition on the calorific value of the selected biological materials. Agric. Eng. 2016, 20, 177-183. [CrossRef]

33. Ciesielczuk, T.; Karwaczyńska, U.; Sporek, M. The possibility of disposing of spent coffee ground with energy recycling. J. Ecol. Eng. 2015, 16, 133-138. [CrossRef]

34. Somnuk, K.; Eawlex, P.; Prateepchaikul, G. Optimization of coffee oil extraction from spent coffee grounds using four solvents and prototype-scale extraction using circulation process. Agric. Nat. Resour. 2017, 51, 181-189. [CrossRef]

35. Caetano, N.; Silva, V.; Mata, T.M. Valorization of coffee grounds for biodiesel production. Chem. Eng. Trans. 2012, 26, 267-272.

36. Zuorro, A.; Lavecchia, R. Spent coffee grounds as a valuable source of phenolic compounds and bioenergy. J. Clean. Prod. 2012, 34, 49-56. [CrossRef]

37. Pujol, D.; Liu, C.; Gominho, J.; Olivella, M.À.; Fiol, N.; Villaescusa, I.; Pereira, H. The chemical composition of exhausted coffee waste. Ind. Crop. Prod. 2013, 50, 423-429. [CrossRef] 
38. Atabani, A.E.; Mercimeka, S.M.; Arvindnarayan, S.; Shobana, S.; Kumar, G.; Cadir, M.; Al-Muhatseb, A.H. Valorization of spent coffee grounds recycling as a potential alternative fuel resource in Turkey: An experimental study. J. Air Waste Manag. Assoc. 2018, 68, 196-214. [CrossRef] [PubMed]

39. Tsai, W.T.; Liu, S.C.; Hsieh, C.H. Preparation and fuel properties of biochars from the pyrolysis of exhausted coffee residue. J. Anal. Appl. Pyrol. 2012, 93, 63-67. [CrossRef]

40. ISO. Solid Biofuels_Determination of Mechanical Durability of Pellets and Briquettes_Part 2: Briquettes; ISO: Geneva, Switzerland, 2015.

41. Cubero-Abarca, R.; Moya, R.; Valaret, J.; Filho, M.T. Use of coffee (Coffea arabica) pulp for the production of briquettes and pellets for heat generation. Ciência e Agrotecnologia 2014, 38, 461-470. [CrossRef]

42. Brunerová, A.; Roubík, H.; Brožek, M. Bamboo fiber and sugarcane skin as a bio-briquette fuel. Energies 2018, 11, 2186. [CrossRef]

43. Karunanithy, C.; Wang, Y.; Muthukumarappan, K.; Pugalendhi, S. Physiochemical characterization of briquettes made from different feedstocks. Biotechnol. Res. Int. 2012, 2012, 165202. [CrossRef] [PubMed]

44. Adapa, P.; Tabil, L.; Schoenau, G. Compaction characteristics of barley, canola, oat and wheat straw. Biosyst. Eng. 2009, 104, 335-344. [CrossRef]

45. Chiteculo, V.; Brunerová, A.; Surový, P.; Brožek, M. Management of Brazilian hardwood species (Jatoba and Garapa) wood waste biomass utilization for energy production purposes. Agron. Res. 2018, 16, 365-376. [CrossRef]

46. Brunerová, A.; Pecen, J.; Brožek, M.; Ivanova, T. Mechanical durability of briquettes from digestate in different storage conditions. Agron. Res. 2016, 14, 327-336.

47. Eissa, A.H.A.; Alghannam, A.R.O. Quality characteristics for agriculture residues to produce briquette. World Acad. Sci. Eng. Technol. 2013, 78, 166-171.

48. Repsa, E.; Kronbergs, E.; Pudans, E. Durability of compacted energy crop biomass. Eng. Rural Dev. 2014, 13, 436-439.

49. Tumuluru, J.S.; Tabil, L.G.; Song, Y.; Iroba, K.L.; Meda, V. Impact of process conditions on the density and durability of wheat, oat, canola, and barley straw briquettes. Bioenergy Res. 2015, 8, 388-401. [CrossRef]

50. Brožek, M. The effect of moisture of the raw material on the properties briquettes for energy use. Acta Universitatis Agriculturae et Silviculturae Mendelianae Brunensis 2016, 64, 1453-1458. [CrossRef]

51. Brunerová, A.; Müller, M.; Brožek, M. Potential of wild growing Japanese knotweed (Reynoutria japonica) for briquette production. In Proceedings of the 16th International Scientific Conference Engineering for Rural Development, Jelgava, Latvia, 24-26 May 2017; pp. 561-568.

52. Brožek, M. Evaluation of selected properties of briquettes from recovered paper and board. Res. Agric. Eng. 2015, 61, 66-71. [CrossRef]

53. Brunerová, A.; Brožek, M.; Müller, M. Utilization of waste biomass from post-harvest lines in the form of briquettes for energy production. Agron. Res. 2017, 15, 344-358. 